TARNOWSKIE STUDIA TEOLOGICZNE 36 (2017) NR 2, s. 43-6o http://dx.doi.org/10.15633/tst.2614

ks. Piotr Przyby $1^{1}$

UNIWERSYTET PAPIESKI JANA PAWŁA II W KRAKOWIE

\title{
Czy zmartwychwstanie Jezusa Chrystusa jest faktem naukowym?
}

„A jeśli Chrystus nie zmartwychwstał, daremne jest nasze nauczanie, próżna jest także wasza wiara" (1 Kor 15, 14) ${ }^{2}$. Te słowa św. Pawła z Listu do Koryntian świadczą o tym, jak fakt zmartwychwstania Jezusa Chrystusa jest ważny dla chrześcijaństwa. Czy ten fundament wiary może znaleźć potwierdzenie w świecie nauki? Celem artykułu jest próba odpowiedzi na to pytanie. Temat został podjęty najpierw z perspektywy Biblii i teologii dogmatycznej (chrystologii). Następnie przechodzi do apologii popularnej ewangelizatora amerykańskiego - Josha McDowella, której celem jest udowodnienie zmartwychwstania za pomocą badań historycznych. Zaś krytyka tej apologii zostanie ukazana z perspektywy poglądów Michała Hellera, księdza katolickiego, a zarazem filozofa i naukowca, który proponuje rozumienie naturalizmu metodologicznego dające się pogodzić z możliwością działania Boga w świecie.

\section{Świadectwo Pisma Świętego}

Zmartwychwstanie Jezusa apostołowie od początku uczynili fundamentem swojego orędzia: „Tymczasem jednak Chrystus zmartwychwstał jako pierwszy spośród tych, co pomarli" (1 Kor 15, 20). Pozytywne orędzie głoszonej Ewangelii wsparte było apologią na temat realnej śmierci, prawdziwego zmartwychwstania Jezusa i Jego ukazywania się wielu osobom, których świadectwo było dowodem prawdziwości tego faktu:

1 Piotr Przybył, ksiądz katolicki diecezji kaliskiej, doktorant z filozofii przyrody na Uniwersytecie Papieskim Jana Pawła II w Krakowie.

2 Wszystkie cytaty z Pisma Świętego pochodzą z Biblii Tysiąclecia (Poznań 20o65). 
Przekazałem wam na początku to, co przejąłem: że Chrystus umarł - zgodnie z Pismem - za nasze grzechy, że został pogrzebany, że zmartwychwstał trzeciego dnia, zgodnie z Pismem: i że ukazał się Kefasowi, a potem Dwunastu, później zjawił się więcej niż pięciuset braciom równocześnie; większość z nich żyje dotąd, niektórzy zaś pomarli. Potem ukazał się Jakubowi, później wszystkim apostołom. W końcu, już po wszystkich, ukazał się także i mnie jako poronionemu płodowi (1 Kor 15, 3-8).

Orędzie chrześcijańskie, osadzone na fundamencie wskrzeszenia Jezusa z martwych, rozprzestrzeniło się szybko dzięki temu, że wiązało się jednocześnie z uniwersalizmem zmartwychwstania, który otwiera przed człowiekiem perspektywę soteriologiczną, możliwość życia po śmierci: „Ponieważ bowiem przez człowieka [przyszła] śmierć, przez człowieka też dokona się zmartwychwstanie. I jak w Adamie wszyscy umierają, tak też w Chrystusie wszyscy będą ożywieni” (1 Kor 15, 21n).

Kardynał Gerhard Ludwig Müller, prefekt Kongregacji Nauki Wiary w podręczniku chrystologii stwierdza:

Dzieło Bożej mocy wskrzeszenia wykracza poza ramy przyrodzonego doświadczenia i możliwości empirycznej weryfikacji. [...] Paschalne wydarzenie staje się empirycznie uchwytne dzięki ukazywaniu się Zmartwychwstałego (chrystofanie) i relacjom świadków3.

Ewangelie w opisach zmartwychwstania zawierają żywe relacje o objawieniach Chrystusa oraz wzajemne opowieści świadków tego wydarzenia, lecz nie ma w nich żadnych danych, które mogłyby być istotne dla uzyskania empirycznych dowodów. Dzieło ewangelizacji prowadzonej przez apostołów po zesłaniu Ducha Świętego w dniu Pięćdziesiątnicy było ich osobistym świadectwem spotkania Zmartwychwstałego. Ta metoda głoszenia nowiny o zbawieniu, wsparta wcześniej wspomnianym uniwersalizmem, przyniosła ogromne efekty - wspólnota Kościoła rozprzestrzeniła się po świecie w zaskakująco szybkim tempie. Najpierw chrześcijaństwo zapanowało w całym Cesarstwie Rzymskim, a następnie ekspandowało

3 G. L. Müller, Chrystologia - nauka o Jezusie Chrystusie. Podręcznik teologii dogmatycznej, tłum. W. Szymona, Kraków 1998, s. 227. 
na kolejne obszary ziemi i dziś liczba chrześcijan szacowana jest na ponad dwa miliardy ludzi ${ }^{4}$.

\section{Perspektywa chrystologiczna}

Cała chrystologia zawarta w księgach Nowego Testamentu jest spisana z perspektywy zmartwychwstania, w której Jezus odczytywany jest jako Chrystus, Mesjasz, Pan i Syn Boży. W ten sposób wiara w zmartwychwstanie pozostaje w ścisłym związku z uznaniem bóstwa Jezusa, a więc obrona realności tego faktu staje się jednocześnie apologią samego Chrystusa i kluczowym zagadnieniem chrystologii oraz teologii fundamentalnej.

W chrystologii jasno wskazuje się, że w przypadku zmartwychwstania Jezusa nie chodzi o żadne metaforyczne bytowanie w jakimś innym wymiarze czy przestrzeni, lecz realne życie:

Zmartwychwstania nie można utożsamiać z (dla medycyny niemożliwą) reanimacją martwego ciała. Nie chodzi tu też o dalsze życie duszy po śmierci w raju. [...] Zatem przez zmartwychwstanie Jezus nie przenosi się do jakiegoś zaświatowego miejsca przebywania zmarłych. [...] Osobowy byt Jezusa [...] teraz - przez wskrzeszenie Go z martwych - otrzymuje swą definitywną formę 5 .

Ta „definitywna forma” oznacza Jego nową egzystencję jako człowieka, a jednocześnie wskazuje na transcendentalną relację Chrystusa jako Boga do całego stworzenia ${ }^{6}$. Zmartwychwstanie oznacza, że „Jezus żyje doskonałym życiem u Boga. Bóg udziela Mu się jako źródło tego życia, którym Go wypełnia"'.

W chrystologii jasno podkreśla się ponadto niemożność naukowego ujęcia zmartwychwstania:

Ale dla przyrodzonego widzenia i poznania pozostaje On niedostępny. Jezus musi się sam dać poznać i czyni to zupełnie dobrowolnie. W akcie samoobjawienia

4 Na podstawie raportu sporządzonego przez Pew Research Center on Religion \& Public Life, Global Christianity - A Report on the Size and Distribution of the World's Christian Population, http://www.pewforum.org/files/2011/12/Christianity-fullreport-web.pdf (5.04.2017).

5 G. L. Müller, Chrystologia..., s. 233.

6 Zob. G. L. Müller, Chrystologia..., s. 233.

7 G. L. Müller, Chrystologia..., s. 233. 
się daje uczniom możliwość zidentyfikowania Go przez wiarę. [...] Jezus jest niedostępny dla poznania zmysłowego, dlatego też wiara w Zmartwychwstałego nie może być produktem twórczej wyobraźni ${ }^{8}$.

Przedmiotem badań i analiz w chrystologii są zatem chrystofanie i formuły użyte do ich opisu oraz relacje świadków i ich wiarygodność. W teologii fundamentalnej istotne jest uzasadnienie realnej śmierci Jezusa, ukazywanie realności pustego grobu oraz podkreślanie cielesności zmartwychwstałego dla odrzucenia hipotezy o zjawie czy duchu'.

Współcześnie dogmat wiary nie jest przez ludzi przyjmowany bezkrytycznie, często przeciwstawia się mu „dogmat nauki” nakazujący, by wszystko udowodniać w sposób naukowy, czyli za pomocą metody matematyczno-empirycznej. Człowiek wierzący, który nie jest obeznany ze światem nauki, a jednocześnie nie śledzi rozpraw teologicznych, łatwo może się pogubić. Niekoniecznie postrada on wiarę lub straci zaufanie do nauki, lecz nie będzie zdolny uzasadnić swoich przekonań oraz wskazać poprawnych argumentów wspierających jego wiarę. Do takiego odbiorcy kierowana jest tak zwana „apologia popularna” pisana nie tyle przez teologów czy naukowców, co głosicieli Ewangelii.

\section{Apologia popularna McDowella}

Autor tej dysertacji posłużył się przykładem apologii popularnej napisanej przez McDowella, amerykańskiego teologa chrześcijańskiego wyznania ewangelickiego, a jednocześnie mówcy, pisarza, popularyzatora wiary i ewangelizatora. Wybór może zostać uznany za niewłaściwy ze względu na jawnie ewangelizacyjny, a więc tendencyjny charakter tej apologii. Niemniej jednak trzeba podkreślić, że twórczość McDowella jest szeroko znana w świecie i wpływa w zasadniczy sposób na świadomość ludzi wierzących. Najpopularniejsze dzieło tego pisarza - More than a Carpenter ${ }^{10}$ - zostało przetłumaczone na ponad 80 języków w milionach egzemplarzy, a czasopismo „World Magazine” uznało inną publikację: The New Evidence that

${ }^{8}$ G. L. Müller, Chrystologia..., s. 233-234.

9 Zob. G. L. Müller, Chrystologia..., s. 234-237.

${ }^{10}$ Polskie wydanie: J. McDowell, Więcej niż Cieśla, tłum. J. Kozłowski, Warszawa 1996. 
Demands a Verdict ${ }^{11}$ za jedną z najbardziej wpływowych książek dwudziestego stulecia ${ }^{12}$. Kluczowe $\mathrm{w}$ tej pracy będzie odniesienie poglądów tego chrześcijańskiego pisarza do stanowiska Hellera, również teologa chrześcijańskiego, ale jednocześnie filozofa i naukowca, który stosując krytyczny racjonalizm, broni porządku metodologicznego nauki, a jednocześnie w swojej teologii naturalnej wskazuje na obecność i działanie Boga w świecie.

McDowell w książce (Nie)? wiarygodne zmartwychwstanie ${ }^{13}$ stara się dotrzeć do szerokiego grona odbiorców, ukazując możliwość (która jego zdaniem zachodzi) pogodzenia dogmatu o zmartwychwstaniu Jezusa $\mathrm{z}$ naukowym obrazem świata. Ambicją autora jest odnalezienie naukowych dowodów na istnienie pustego grobu. Powstanie Jezusa $\mathrm{z}$ martwych to konkretne wydarzenie historyczne i jako takie powinno być badane oraz dowodzone.

\section{Dowodzenie historyczne}

W swej apologii McDowell skupia się na kilku zagadnieniach, takich jak: (1) autentyczność Ewangelii potwierdzająca historyczność Jezusa, (2) pewność śmierci Chrystusa, (3) szczegóły pochówku wskazujące na brak możliwości wykradzenia ciała, (4) sam moment zmartwychwstania, (5) obalenie teorii alternatywnych.

W kwestii autentyczności (1) McDowell wskazuje na wyniki historycznych badań dokumentów, potwierdzenie pochodzące $\mathrm{z}$ archeologii biblijnej, relacje świadków zawarte w Biblii (ze szczególnym uwzględnieniem świadków wrogich chrześcijaństwu), świadectwa pozabiblijne o Jezusie i obecność pierwszych wspólnot, do których adresowane były listy apostolskie Nowego Testamentu ${ }^{14}$.

W odniesieniu do zagadnienia pewnej śmierci Chrystusa (2) autor apologii, na podstawie opisów historycznych krzyżowania i szczegółów zawartych

${ }^{11}$ J. McDowell, The New Evidence that Demands a Verdict, San Bernardino 1991.

${ }_{12}$ Dane pochodzą z biogramu Josha McDowella umieszczonego na oficjalnej stronie jego duszpasterstwa. Zob. Josh's bio, http://www.josh.org/about-us/joshs-bio (5.04.2017).

${ }_{13}$ J. McDowell, S. McDowell, (Nie)? wiarygodne zmartwychwstanie, tłum. E. Małecka, Warszawa 2009. Tłumaczenie tytułu nie jest zbyt dokładne. Tytuł oryginału to: The Credible Resurrection, czyli po prostu Wiarygodne zmartwychwstanie.

${ }^{14}$ Zob. J. McDowell, S. McDowell, (Nie)? wiarygodne zmartwychwstanie, s. 185-214; J. McDowell, Więcej niż Cieśla, s. 36-52. 
w relacji biblijnej, oraz nadzorowania wykonania wyroku przez władze cesarstwa, wnioskuje o pewnej śmierci Jezusa ${ }^{15}$.

Szczegóły pochówku Jezusa (3) opisane w Biblii zgadzają się z żydowskimi zwyczajami pogrzebowymi. Ponadto zabezpieczenia władzy rzymskiej (kamień, straże, pieczęć) obalają jego zdaniem teorię o wykradzeniu ciała przez apostołów ${ }^{16}$.

\section{Fakt zmartwychwstania}

W samym momencie zmartwychwstania (4), zdaniem McDowella, można wyróżnić kilka faktów:

Fakt 1: pieczęć jest złamana.

Fakt 2: kamień został odsunięty.

Fakt 3: grób jest pusty.

Fakt 4: straż oddala się z posterunku.

Fakt 5: płótna są dowodem („ujrzał i uwierzył”).

Fakt 6: Jezus ukazuje się ludziom jako żywy.

Wszystkie te fakty są jasnym wskazaniem, że w ten niedzielny poranek, doszło do jakiegoś nadzwyczajnego wydarzenia. Grób jest pusty, a ciężki kamień chroniący dostępu do niego jest odsunięty w niewytłumaczalny sposób. Pieczęć cesarska została złamana, co oznaczało jawne pogwałcenie prawa rzymskiego. Straż oddala się z posterunku, za co grozi im śmierć. Ponadto wartownicy zawierają z kapłanami żydowskimi układ, który jest dla nich niekorzystny, niebezpieczny i nie daje im żadnej gwarancji, iż zostanie dotrzymany. Strażnicy bowiem zeznając, że usnęli na posterunku, również ściągaliby na siebie śmierćt ${ }^{17}$ W Ewangelii św. Jana, autor podkreśla istotne znaczenie płócien:

A pierwszego dnia po szabacie, wczesnym rankiem, gdy jeszcze było ciemno, Maria Magdalena udała się do grobu i zobaczyła kamień odsunięty od grobu. Pobiegła więc i przybyła do Szymona Piotra i do drugiego ucznia, którego Jezus

15 Zob. J. McDowell, S. McDowell, (Nie)? wiarygodne zmartwychwstanie, s. 215-231.

${ }^{16}$ Zob. J. McDowell, S. McDowell, (Nie)? wiarygodne zmartwychwstanie, s. 232-254; J. McDowell, Więcej niż Cieśla, s. 78-79.

${ }_{17}$ Zob. J. McDowell, Więcej niż Cieśla, s. 8 o. 
kochał i rzekła do nich: «Zabrano Pana z grobu i nie wiemy, gdzie Go położono». Wyszedł więc Piotr i ów drugi uczeń i szli do grobu. Biegli oni obydwaj razem, lecz ów drugi uczeń wyprzedził Piotra i przybył pierwszy do grobu. A kiedy się nachylił, zobaczył leżące płótna, jednakże nie wszedł do środka. Nadszedł potem także Szymon Piotr, idący za nim. Wszedł on do wnętrza grobu i ujrzał leżące płótna oraz chustę, która była na Jego głowie, leżącą nie razem z płótnami, ale oddzielnie zwiniętą na jednym miejscu. Wtedy wszedł do wnętrza także i ów drugi uczeń, który przybył pierwszy do grobu. Ujrzał i uwierzył (J 20, 1-8).

Następnie wszystkie Ewangelie odnotowują dużo relacji o zmartwychwstaniu, Jezus ukazuje się wielu ludziom, w różnych miejscach i odmiennym czasie $^{18}$.

We wszystkich elementach tego wydarzenia dla McDowella istotne jest podkreślanie słowa „fakt”. Zdaniem autora opis ewangeliczny jest prawdziwy, a więc to, co się wydarzyło, jest pewne, oczywiste jest również odkrycie pustego grobu. Na tym jednak nie kończy się jego historyczne śledztwo, gdyż istnieje jeszcze wiele teorii alternatywnych, z którymi McDowell postanowił się skonfrontować, odrzucając je po kolei.

\section{Koncepcje alternatywne}

Pierwszą alternatywną możliwością jest koncepcja mitu - apostołowie chcąc utrzymać legendę o Jezusie, stworzyli mit, jakoby miał On zmartwychwstać. McDowell kontrargumentuje, twierdząc, że opowieści ewangeliczne nie mają struktury mitu. Poza tym apostołowie, oddając życie w męczeński sposób, zaświadczyli, że to, co głosili było prawdą. Jego zdaniem za mit się nie umiera ${ }^{19}$. Wobec tego możliwe wydaje się, że apostołowie wprawdzie szczerze oddali swoje życie, lecz uczynili to ze względu na halucynacje, jakim ulegli. Chrystofanie jednak dzieją się w różnych miejscach, w różnym czasie, wobec różnych świadków, co zdaniem McDowella wyklucza tę teorię $e^{20}$.

${ }_{18}$ Zob. J. McDowell, S. McDowell, (Nie)? wiarygodne zmartwychwstanie, s. 255-272.

19 Zob. J. McDowell, S. McDowell, (Nie)? wiarygodne zmartwychwstanie, s. 275-277; J. McDowell, Więcej niż Cieśla, s. 52-67.

${ }^{20}$ Zob. J. McDowell, S. McDowell, (Nie)? wiarygodne zmartwychwstanie, s. 285-292. 
Podobnie należy odrzucić przypuszczenie, jakoby apostołowie mieli na myśli zmartwychwstanie duchowe, gdyż wszystkie relacje zawierają jasne stwierdzenia, że Jezus żyje ${ }^{21}$.

Hipoteza innego grobu, jak i wykradzenia ciała ${ }^{22}$ wydaje się niemożliwa ze względu na zastosowane przez władzę środki ostrożności - straż przy grobie, pieczęć cesarską i kamień u wejścia.

Wszelkie teorie podważające śmierć Jezusa, na przykład: substytucja, czyli ewentualna zamiana skazańca ${ }^{23}$, czy reanimacja rozumiana jako przywrócenie funkcji życiowych ${ }^{24}$, należy odrzucić ze względu na precyzyjny opis męki, który jasno wskazuje na śmierć Jezusa. Ponadto istotny jest nadzór władzy pilnującej dokonania wyroku.

Zdaniem McDowella przedstawione przez niego argumenty są wystarczające, by przynajmniej pusty grób uznać za historyczny, co wskazuje ponadto na możliwość, że Jezus faktycznie zmartwychwstał ${ }^{25}$. Oczywiście wobec jego argumentacji można wysnuć wiele zarzutów i wskazać wiele słabych punktów w jego rozumowaniu. Niemniej jednak, aby temat został podjęty kompleksowo, konieczne byłoby sięgnięcie do całej historii polemiki apologetycznej. Prawie żaden z odbiorców popularnych nie jest zainteresowany tak szerokim opracowaniem, więc jego wybór ograniczy się do lektury tej lub podobnych książek. Czy te argumenty go przekonają? Zainteresowanie publikacjami McDowella sięgające milionów egzemplarzy wskazuje, że odbiorca tych treści otrzymuje przynajmniej dobrą pomoc umożliwiającą mu własne ustosunkowanie się do tego zagadnienia.

\section{Zagadnienie cudu w kontekście nauki}

Interesująca w tym kontekście wydaje się następująca kwestia: w jaki sposób McDowell chce wskazać naukowy dowód nie tyle istnienia pustego grobu - który może po prostu pozostawać pewną zagadką czy ciekawostką

${ }^{21}$ Zob. J. McDowell, S. McDowell, (Nie)? wiarygodne zmartwychwstanie, s. 281-285.

${ }^{22}$ Zob. J. McDowell, S. McDowell, (Nie)? wiarygodne zmartwychwstanie, s. 298-305; J. McDowell, Więcej niż Cieśla, s. 82-83.

${ }_{23}$ Zob. J. McDowell, S. McDowell, Nie)? wiarygodne zmartwychwstanie, s. 292-295.

${ }^{24}$ Zob. J. McDowell, S. McDowell, (Nie)? wiarygodne zmartwychwstanie, s. 305-311; J. McDowell, Więcej niż Cieśla, s. 81-82.

${ }^{25}$ Zob. J. McDowell, S. McDowell, (Nie)? wiarygodne zmartwychwstanie, s. 311-312. 
historyczną, co samego zmartwychwstania - jako cudu, wyrazu działania Boga w świecie, a więc jednocześnie dowodu na Jego istnienie.

McDowell w swojej apologii wskazuje na niemożność empirycznego potwierdzenia faktu historycznego. W tym przypadku jednak miało dojść do cudu - czegoś, co nauka przyjmująca naturalizm metodologiczny odrzuca niezależnie od wszelkich danych historycznych ${ }^{26}$. McDowell przedstawia własną koncepcję cudu i wyraża odmienne stanowisko względem podejścia naukowego. Cud według niego jest:

wydarzeniem spowodowanym przez bezpośrednie działanie Boga, w którym prawa natury zostają tymczasowo zawieszone, aby osiągnąć cel, nieosiągalny w obrębie działania tych stałych praw ${ }^{27}$.

Zdaniem McDowella naturalizm metodologiczny, odrzucając możliwość cudów, sam domaga się uzasadnienia i takiego w pełni nie znajduje - nie ma potwierdzenia, iż świat jest układem zamkniętym, w którym sprawdza się jedna metoda. Takie stanowisko można według niego uznać po prostu za pewną orientację filozoficzną, nie mniej uprawnioną od innych. McDowell uważa więc, że również w nauce należy dopuścić możliwość zaistnienia cudu i później surowo oceniać za pomocą badań historycznych. W ten sposób cud może zostać włączony w dyskurs naukowy ${ }^{28}$.

Pogląd McDowella jest kontrowersyjny i w świecie nauki nie znajduje swojego miejsca, gdyż uznając cud w jednym przypadku, można całą rzeczywistość uznać za cud i zaprzestać uprawiania nauki w ogóle, a za jedyną metodę poznania „naukowego” przyjąć mistycyzm. Nauka, uznając cud, zaprzecza sama sobie. Badania naukowe mogą zakończyć się jedynie konkluzją, że dla niej samej dane zagadnienie pozostaje niewyjaśnione, przynajmniej przy obecnym stanie wiedzy. Naukowcy nie wykluczają możliwości odkrycia w przyszłości uzasadnienia czysto empirycznego.

${ }^{26}$ Zob. J. McDowell, S. McDowell, (Nie)? wiarygodne zmartwychwstanie, s. 154-163; J. McDowell, Więcej niż Cieśla, s. 32-35.

${ }^{27}$ J. McDowell, S. McDowell, (Nie)? wiarygodne zmartwychwstanie, s. 167.

${ }^{28}$ Zob. J. McDowell, S. McDowell, (Nie)? wiarygodne zmartwychwstanie, s. 267-277. 


\section{Krytyczny racjonalizm Hellera}

Jak w tej panoramie poglądów przedstawia się stanowisko Hellera - teologa, filozofa i naukowca zarazem? Polski kosmolog w swojej filozofii i teologii naturalnej dąży do zintegrowania świata nauki i teologii, za co w 2008 roku otrzymał nagrodę Templetona ${ }^{29}$. Przedmiotem jego zainteresowań są nauki ścisłe, szczególnie matematyka i fizyka w zastosowaniu do badań nad Wszechświatem. Filozofia nauki Hellera jest mocno zakorzeniona w samej nauce. Czerpiąc inspirację z myśli Karla Poppera, polski filozof zwraca uwagę na dużą rolę konstruktywnej krytyki teorii naukowych, która oparta jest na analizie wyników badań empirycznych oraz wyszukiwaniu założeń ukrytych w teoriach. Kluczową rolę należy więc przypisać falsyfikacjonizmowi i pewnemu rodzajowi metodycznego fallibilizmu, który za Popperem nazywa „krytycznym racjonalizmem”, a który oznacza badanie i podawanie w wątpliwość poglądów i teorii cudzych, ale także swoich własnych ${ }^{30}$.

Heller, dokonując dogłębnej i systematycznej refleksji nad nauką, zauważa, że największe sukcesy w zdobywaniu ludzkiej wiedzy dokonały się dzięki metodzie matematyczno-empirycznej. Niemniej jednak metoda wskazuje na swoje ograniczenia, jak choćby to, że ona sama domaga się uzasadnienia, które jak można przypuszczać, pochodzi spoza niej. Słusznie więc upadł neopozytywizm głoszący skrajny empiryzm, gdyż negował on możliwość uprawiania takich nauk, jak choćby historia, filozofia czy teologia. Zdaniem Hellera wszystkie te nauki są uprawnione, trzeba jednak pamiętać, że żadne $\mathrm{z}$ ich tez nie mogą być sprzeczne z tym, co o świecie mówią nauki empirycz$n e^{31}$. Filozofia jest konieczna, gdyż zawsze, w każdej teorii i twierdzeniach, znajdują się pewne założenia metafizyczne, ale należy pamiętać, że również każda ontologia sprzeczna $\mathrm{z}$ dokonaniami nauki powinna zostać obalona, podobnie jak na przykład filozofia mechanicyzmu w obliczu osiągnięć fizyki z przełomu xıx i xx wieku. W ten sposób filozofia staje się bardzo ważnym narzędziem dla nauk i sama może przyjmować dojrzałą postać i rozwijać się w kierunku odkrywania prawdy o świecie ${ }^{32}$.

${ }^{29}$ Zob. Previous pre winners. Michal Heller, http://www.templetonprize.org/previouswinners/heller.html (5.04.2017).

${ }^{30}$ Zob. M. Heller, Usprawiedliwienie wszechświata, Kraków 1984, s. 12.

${ }^{31}$ Zob. M. Heller, Filozofia i wszechświat, Kraków 2008, s. 31-33.

${ }^{32}$ Zob. M. Heller, Logos wszechświata, Kraków 2013, s. 205-210; M. Heller, Filozofia przyrody. Zarys historyczny, Kraków 2007, s. 191-195. 
Podobnie teologia, zdaniem Hellera, jest zależna od obecnego obrazu świata. Dlatego też teolog w swoich rozważaniach powinien uwzględniać obraz świata, który współcześnie kształtowany jest przez naukę oraz język dynamicznie zależny od dyskursu naukowego ${ }^{33}$. Filozofia ani teologia nie może być więc zamkniętym systemem. Heller głosi antyfundacjonizm sprzeciwia się wszelkim systemom, poszukuje wiedzy, która nie jest oparta na żadnych aksjomatach czy fundamentach ${ }^{34}$.

\section{Cuda a naturalizm metodologiczny}

W jaki sposób takie krytyczne i antysystemowe podejście do wszelkich nauk i źródeł wiedzy wpływa na postrzeganie zagadnień teologicznych przez Hellera? Tematyką samych cudów nie zajmuje się on bezpośrednio, choć w całości poglądów polskiego kosmologa można odnaleźć obszary, które jasno określają jego stosunek do rozpatrywania cudów przez teologię i naukę empiryczną. Najbardziej uwidacznia się to w teologii naturalnej, w ramach której rozważa możliwość działania Boga w świecie.

Przyglądając się temu zagadnieniu od strony negatywnej, Heller dostrzega częsty błąd popełniany zarówno przez teologów, jak i naukowców, który został nazwany mianem God of the gaps (Bóg od [zapychania] dziur). Skoro Bóg dokonuje w świecie cudów, których nauka nie potrafi wyjaśnić, to również naturalne zjawiska mogą zostać uznane za pole działania Boga. Tego typu twierdzenia stały się szczególnie popularne w momencie powstania mechaniki kwantowej. Nawet dziś teologowie nieznający aparatu matematycznego tej teorii fizycznej widzą możliwość interwencji Bożej na poziomie probabilistycznym, który przejawia się w najmniejszych skalach Wszechświata. Podobny problem powstał w kontekście teorii kosmologicznej o Wielkim Wybuchu, który wielu interpretuje jako początek świata i równa $\mathrm{z}$ momentem stworzenia. Takie twierdzenie nie różni się od poprzedniego, z jednym wyjątkiem - dziura, którą miałby „załatać” Bóg znajduje się na samym (być może pozornym) początku. Tymczasem już dawno w myśli teologicznej początek świata został odróżniony od momentu stworzenia - pisali o tym między innymi św. Augustyn i św. Tomasz z Akwinu. Heller takie stanowisko

${ }^{33}$ Zob. M. Heller, Nowa fizyka i nowa teologia, Tarnów 1992, s. 83-95; M. Heller, Granice nauki, Kraków 2014, s. 205-211.

${ }^{34}$ Zob. M. Heller, Filozofia i wszechświat, s. 82-85. 
określa jako błąd, zarówno teologiczny, jak i metodologiczny, gdyż wiąże się ono z niewłaściwą interpretacją Bożej wszechmocy oraz jej ujawniania się w świecie, a ponadto zaprzecza metodzie naukowej ${ }^{35}$. Polski kosmolog jest zwolennikiem naturalizmu metodologicznego, co wyraża w sformułowaniu: „usprawiedliwienie W szechświata”36. Jego zdaniem Wszechświat domaga się usprawiedliwienia, czyli uzasadnienia jego istnienia, tak samo, jak odpowiedzi wymaga pytanie Leibniza: „Dlaczego istnieje raczej coś aniżeli nic?” Metoda nauki wymaga, aby ta justyfikacja dokonywała się za pomocą samego Uniwersum, i to nawet w odniesieniu do zagadnienia jego początku³7

\section{Monizm metodologiczny a koncepcja chrześcijańska}

Czy metodologiczny naturalizm jest do pogodzenia z dopuszczalnością działania Boga we świecie? W religii chrześcijańskiej podstawowymi dogmatami wiary są dwa cuda jawnie burzące porządek natury, czyli wcielenie Syna Bożego i Jego późniejsze zmartwychwstanie. Ta ingerencja Boga jest konieczna do uzasadnienia wiary w bóstwo Jezusa. Heller pisze o prologu Ewangelii św. Jana (J, 1-18) jako o teologicznej interpretacji, według której Logos, czyli Słowo (ale i Racjonalność, Rozum) pochodzące od Boga i będące samym Bogiem, weszło w historię człowieka ${ }^{38}$. Dopuszczenie jednego cudu oznacza możliwość wszelkiego działania Boga w świecie. Czy zatem Heller przeczy sam sobie?

Naturalizm metodologiczny jest monizmem, podczas gdy w chrześcijaństwie wydaje się panować dualizm - to, co boskie, i świat. Heller, próbując skonfrontować i scalić te stanowiska, stawia problem, który nazywa - przez nawiązanie do tradycji - preambulum fidei $i^{39}$. Powołuje się na Willema Dreesa definicję naturalizmu:

Świat badany przez nauki przyrodnicze stanowi całość rzeczywistości, o której wiemy cokolwiek i z którą możemy wchodzić w kontakt (interract); żaden

35 Zob. M. Heller, Sens życia i sens wszechświata, Kraków 2014, s. 150-155; M. Heller, Filozofia kosmologii, Kraków 2013, s. 145-149.

${ }^{36}$ Michał Heller w ten sposób zatytułował jedną ze swoich książek.

${ }_{37}$ Zob. M. Heller, Granice nauki, s. 200-203.

${ }^{8}$ Zob. M. Heller, Ostateczne wyjaśnienia wszechświata, Kraków 2008, s. 155-163.

${ }^{39}$ M. Heller, Sens życia i sens wszechświata, s. 144. 
nadprzyrodzony lub duchowy obszar, różny od świata naturalnego, nie ujawnia się wewnątrz tego świata, nawet w umysłowym życiu ludzi ${ }^{40}$.

Takie ujęcie naturalizmu wydaje się być nie do przyjęcia dla chrześcijanina, ale zdaniem Hellera istnieje odpowiedź, która może być satysfakcjonująca:

Teza monistyczna, która byłaby do zaakceptowania przez chrześcijańskiego myśliciela, stwierdzałaby, że Bóg nie działa na świat poprzez jakieś nadzwyczajne interwencje, lecz zawsze poprzez naturalny bieg świata. Jego działanie nie ujawnia się w naturalnym biegu świata, nie dlatego, że Jego działania tam nie ma, ale dlatego, że cały naturalny bieg świata jest Jego działaniem ${ }^{41}$.

Tak sformułowany monizm zakłada immanencję Boga w świecie, bez konieczności powoływania się na działanie Boże za pomocą czegoś, co można nazwać „specjalnymi dekretami”, które łamią prawa natury. Ten błąd popełnia właśnie McDowell we własnej definicji cudu jako „wydarzenia spowodowanego przez bezpośrednie działanie Boga, w którym prawa natury zostają tymczasowo zawieszone"42.

Problem ze zrozumieniem działania Boga w świecie, zdaniem Hellera, ma źródło w magicznym pojmowaniu Jego sprawczej wszechmocy - Bóg wypowiada Słowo i natychmiast dzieje się cokolwiek On sam chce. Tymczasem to Słowo musi być rozumiane jako Logos, czyli Kosmiczny Plan, Racjonalność ${ }^{43}$, wtedy zrozumiałe staje się, że to działanie musi być racjonalne.

\section{Działanie Boga jako „Boża Matematyka”}

Zdaniem Hellera działanie Boga może mieć charakter matematyczny, co Leibniz wyraził słowami: „dum Deus calculat, mundus fit” („kiedy Bóg liczy,

${ }^{40}$ W. Drees, Religion, Science and Naturalism, Cambridge 1996, s. 12, za: M. Heller, Sens życia i sens wszechświata, s. 144. Zob. także: W. Drees, Nauka wobec wiary. Spory, debaty, konteksty, Kraków 2016, s. 159-208.

${ }^{41}$ M. Heller, Sens życia i sens wszechświata, s. 144.

${ }^{42}$ J. McDowell, S. McDowell, (Nie)? wiarygodne zmartwychwstanie, s. 167.

${ }^{43}$ Zdaniem Hellera, takie znaczenie Logosu jest zawarte już w opisie stworzenia w Księdze Rodzaju, a bardziej widoczne jest w księgach mądrościowych Starego Testamentu. W Prologu Ewangelii według świętego Jana najbardziej dostrzegalny jest wpływ kultury i języka greckiego na znaczenie semantyczne tego pojęcia. Zob. M. Heller, Sens życia i sens wszechświata, s. 158. 
świat się staje"). Na taką możliwość wskazuje sytuacja, znana naukowcom w codzienności, kiedy to „liczą i świat się staje” - dzieje się tak przy tworzeniu oraz operowaniu modelami matematycznymi, służącymi do opisu pewnego aspektu świata lub jego całości. Model taki jest pewną hierarchią struktur, którym przypisuje się określone cechy rzeczywistości. W ten sposób świat znajduje pewne odwzorowanie w równaniach matematycznych:

W ten sposób skonstruowany model matematyczny nie jest tylko opisem jakiegoś fragmentu lub aspektu świata, ale także jego modelem, to znaczy jakby uproszczoną kopią oryginału, która pod pewnymi względami funkcjonuje (działa) jak oryginał. [...] A więc gdy fizyk-teoretyk liczy, powstaje pewien świat (model), który działa podobnie jak rzeczywisty świat (pod tym względem, który podlega modelowaniu) ${ }^{44}$.

W ten sposób na przykład akt stwórczy można rozumieć jako stworzenie modelu, trzeba jednak pamiętać o zasadniczej różnicy - Bóg stosuje znacznie doskonalszą matematykę od tej nam znanej, i nie chodzi tu tylko o stopień trudności, lecz o całkowicie inną, wyższą jakościowo Jego Matematykę. Ponadto należy zauważyć, że model naukowy, aby został zaaplikowany do opisu świata, musi zostać odpowiednio zinterpretowany, natomiast Bóg po prostu urzeczywistnia daną strukturę matematyczną. W ten sposób Matematyka nie jest już tylko kopią Bożego planu, lecz jest po prostu Bożym planem. Wysiłki naukowców są tylko bardzo małym, częściowym odkrywaniem lub rekonstrukcją Bożej Matematyki, a nasza matematyka jest „Zanurzona” w niej. W ten sposób istnieje możliwość „dotknięcia” Transcendencji. Nigdy jednak nie będzie dane ludzkości w pełni poznać Bożej logiki i sposobu działania Jego Matematyki ${ }^{45}$.

Heller konkluduje swoje rozważania teologiczne, stwierdzając:

W takiej interpretacji działania Boga w świecie nie należy sobie wyobrażać jako «antynaturalistycznych» pchnięć czy nadzwyczajnych interwencji, lecz jako Jego immanentną obecność w świecie i jego prawach. Bóg jest w świecie, ale nie wyczerpuje się w świecie. [...] Wersja chrześcijańskiego naturalizmu, jaką proponuję, nie jest próbą zneutralizowania lub zredukowania tego, co nadnaturalne

${ }^{44}$ M. Heller, Sens życia i sens wszechświata, s. 160.

${ }^{45}$ Zob. M. Heller, Sens życia i sens wszechświata, s. 159-162. 
do naturalnego, lecz polega na zanurzeniu tego, co nazywamy naturalnym, w Niewyczerpalnym Polu Bożej Racjonalności ${ }^{46}$.

Stanowisko przedstawione przez polskiego kosmologa wskazuje na pewien szczególny rodzaj panenteizmu, który mieści się w doktrynie chrześcijańskiej. Poziom, na którym działa Bóg, według tej koncepcji jest zupełnie inny niż przy założeniu interwencjonistycznym. Bóg działa całościowo i wyprzedzająco w stosunku do zastanej przez człowieka rzeczywistości. Wszelkie cuda, ze zmartwychwstaniem Jezusa włącznie, zawarte są w Bożej Racjonalności i zrealizowane w świecie, według tej Racjonalności stworzonym. Zamysł Boży pozostaje jednakże dla człowieka ukryty, transcendentny, więc nie można go poznać, można jedynie przybliżać się do prawdy. Perspektywa naukowa i jej metoda, w tym konkretnym przypadku cudu, pozostaje bezradna. Nawet jeśli metodą badań historycznych uda się stwierdzić $\mathrm{z}$ pewnością istnienie pustego grobu Jezusa, nie da się potwierdzić, że było to skutkiem zmartwychwstania. Takie stwierdzenie może pochodzić tylko od szczególnej interpretacji - interpretacji wiary. Dobrym przykładem są tutaj słowa z wcześniej przytoczonego fragmentu Ewangelii według św. Jana: „Wtedy wszedł do wnętrza także i ów drugi uczeń, który przybył pierwszy do grobu. Ujrzał i uwierzył" (J 20, 8). Drugi uczeń, czyli według Tradycji Jan Apostoł, autor Ewangelii „ujrzał”, czyli zobaczył pusty grób i „uwierzył”, czyli zinterpretował to, co widział, jako fakt zmartwychwstania. W ten sposób światopogląd chrześcijanina jest budowany na fundamencie wiary interpretującej dane rozumu oraz na świadectwie tych, którzy widzieli, którym zostało objawione lub którzy sami doświadczyli działania Zmartwychwstałego - czy to 2000 lat temu, czy dziś współcześnie. To wiara jest warunkiem zbawienia: „albowiem łaską zbawieni jesteście przez wiarę” (Ef 8, 2a).

\section{Podsumowanie}

Wysiłek, jaki podjął w swojej książce McDowell, by dotrzeć do szerokiego grona odbiorców $\mathrm{z}$ własną teorią na temat historycznego istnienia pustego grobu okazał się owocny, co widać w popularności, jaką cieszą się jego publikacje. Jego apologia ma charakter popularny, można więc dostrzec w niej wiele nieścisłości wynikających ze skrótów zastosowanych dla dostosowania

${ }^{46}$ M. Heller, Sens życia i sens wszechświata, s. 162-163. 
treści do wielu czytelników. Niemniej jednak lektura publikacji McDowella pobudza ciekawość ludzką, zachęca do pogłębiania wiedzy oraz pozwala na wstępne, własne ustosunkowanie się do konkretnych zagadnień związanych z wiarą. Należy jednak podkreślić, iż z perspektywy naukowej postulat autora o dopuszczeniu cudu do dyskursu naukowego jest nie do przyjęcia. Heller jasno wskazuje na błąd metodologiczny i teologiczny zawarty w takim myśleniu. Naturalizm metodologiczny, warunek uprawiania nauki, wcale nie wyklucza, jego zdaniem, możliwości działania Boga w świecie, a więc i cudów. Niemniej jednak poziom, na którym Boży zamysł się realizuje, jest zupełnie inny od tego, co głosi interwencjonizm. Bóg działa w porządku naturalnym w sposób określony przy stwarzaniu świata, który jest realizacją Bożej Racjonalności. Cuda, których ludzkość była świadkiem, są zwyczajnym działaniem Boga, którego jednak nie można pojąć ze względu na to, iż Boży Rozum, Logos, jest wobec człowieka niedostępny bez Objawienia. Nie należy więc szukać dowodu na to, że dane wydarzenie było cudem, czy też żądać uznania cudu przez naukę. Zmartwychwstanie Jezusa nie musi burzyć porządku nauki, a ta z kolei stwierdzając swój brak kompetencji w tej i innych kwestiach, nie neguje możliwości wiary w działanie Boże. Zmartwychwstanie nie jest faktem naukowym, co nie znaczy, że nie miało miejsca.

Pierwszym źródłem wiary Kościoła pozostaje więc świadectwo apostołów: „I wiele innych znaków, których nie zapisano w tej książce, uczynił Jezus wobec uczniów. Te zaś zapisano, abyście wierzyli, że Jezus jest Mesjaszem, Synem Bożym, i abyście wierząc mieli życie w imię Jego" (J 20, 30n).

\section{Bibliografia}

Pismo Święte Starego i Nowego Testamentu $w$ przekładzie z języków oryginalnych (Biblia Tysiąclecia), Poznań 20065.

Drees W., Nauka wobec wiary. Spory, debaty, konteksty, Kraków 2016.

Drees W., Religion, Science and Naturalism, Cambridge 1996.

Heller M., Filozofia i wszechświat, Kraków 2008.

Heller M., Filozofia kosmologii, Kraków 2013.

Heller M., Filozofia przyrody. Zarys historyczny, Kraków 2007.

Heller M., Granice nauki, Kraków 2014.

Heller M., Logos wszechświata, Kraków 2013.

Heller M., Nowa fizyka i nowa teologia, Tarnów 1992. 
Heller M., Ostateczne wyjaśnienia wszechświata, Kraków 2008.

Heller M., Sens życia i sens wszechświata, Kraków 2014.

Heller M., Usprawiedliwienie wszechświata, Kraków 1984.

Josh's bio, http://www.josh.org/about-us/joshs-bio (5.04.2017).

McDowell J., McDowell S., (Nie)? wiarygodne zmartwychwstanie, tłum. E. Małecka, Warszawa 2009.

McDowell J., The New Evidence that Demands a Verdict, San Bernardino 1991.

McDowell J., Więcej niż Cieśla, tłum. J. Kozłowski, Warszawa 1996.

Müller G. L., Chrystologia - nauka o Jezusie Chrystusie. Podręcznik teologii dogmatycznej, tłum. W. Szymona, Kraków 1998.

Pew Research Center on Religion \& Public Life, Global Christianity - A Report on the Size and Distribution of the World's Christian Population, http://www. pewforum.org/files/2011/12/Christianity-fullreport-web.pdf (5.04.2017).

Previous pre Winners. Michal Heller, http://www.templetonprize.org/previouswinners/heller.html (5.04.2017).

\section{Streszczenie}

Zmartwychwstanie Jezusa Chrystusa jest jednym z fundamentalnych dogmatów wiary chrześcijańskiej. Czy to wydarzenie może zostać uznane za fakt naukowy? Celem artykułu jest próba odpowiedzi na to pytanie. W pracy tej zostanie przedstawiona apologia popularna Josha McDowella, która stwierdza możliwość udowodnienia tego faktu. Zdanie odmienne zostanie ukazane w poglądach Hellera, który mówi o działaniu Boga w świecie bez naruszania naturalizmu metodologicznego $\mathrm{w}$ nauce.

\section{Słowa kluczowe}

Josh McDowell, Michał Heller, krytyczny racjonalizm, naturalizm, apologia popularna

\section{Summary}

\section{Is the Resurrection of Jesus Christ a Science Fact?}

The Resurrection of Christ is one of the fundamental dogmas of the Christian faith. Can this event be considered as a scientific fact? This article attempts to answer this 
question. In this work will be presented popular apology of Josh McDowell which states the opportunity to prove this fact. The different opinion will be shown in ideas of Michael Heller, which speaks of God's action in the world without compromising methodological naturalism in science.

\section{Keywords}

Josh McDowell, Michał Heller, critical rationalism, naturalism, popular apology 